\title{
Orta ve Geçit Bölgelerine Uygun Otlak Ayrığı (Agropyron cristatum (L.) Gaertn.) Çeşitlerinin Geliştirilmesi
}

\author{
Yaşar KARADA $\breve{G}^{1}$ \\ Selahattin ÇINAR ${ }^{2}$ \\ Mahir ÖZKURT ${ }^{1}$ \\ Rüştü HATİPOĞLU ${ }^{4}$ \\ Tahsin TAŞYÜREK ${ }^{3}$ \\ Sezai GÖKALP3 \\ ${ }^{1}$ Gaziosmanpaşa Üniversitesi, Ziraat Fakültesi, Tarla Bitkileri Bölümü, Tokat \\ ${ }^{2}$ KTMU Ziraat Fakültesi Kırgizistan/ Kilis 7 Aralık Üniversitesi, TBMYO Kilis \\ ${ }^{3}$ Orta Karadeniz Geçit Kuşağı Tarımsal Araştırma İstasyonu Müdürlüğü, Tokat \\ ${ }^{4}$ Çukurova Üniversitesi, Ziraat Fakültesi, Tarla Bitkileri Bölümü, Adana \\ $\bowtie$ : scinar01@hotmail.com
}

Geliş (Received): 02.11.2017

Kabul (Accepted): 15.12.2017

ÖZET: $\mathrm{Bu}$ araştırma, 2013-2015 yılları arasında Tokat ve Sivas ekolojik koşullarında otlak ayrı̆̆ı (Agropyron cristatum (L.) Gaertn.) çeşit adayının ot verimi ve ot kalitesini belirlemek amaciyla yürütülmüştür. Araştırmada, bir çeşit adayı ve iki popülasyon, materyal olarak kullanılmıştır. Denemeler iki lokasyonda (Tokat Orta Karadeniz Geçit Kuşağı Tarımsal Araştırma İstasyonu Müdürlüğü, Sivas-Şarkışla Yem Bitkileri Üretim İstasyonu), dört tekrarlamalı, tesadüf blokları deneme desenine uygun olarak yürütülmüştür. Araştırmanın sonuçları, incelenen popülasyon ve çeşit adayının ot verimlerinin ve ot kalitelerinin önemli derecede farklılık gösterdiğini ortaya koymuştur. İki yıllık ortalamalara göre Tokat ve Sivas lokasyonunda sirasıyla en yüksek bitki boyu $(67.0,84.5 \mathrm{~cm})$, yaş ot verimi (1405.6, $1595.4 \mathrm{~kg}$ da-1) ve kuru ot verimi $(570.6,680.9 \mathrm{~kg}$ da-1) çeşit adayında saptanmıştır. Çeşit adayı 2016 yılı içerisinde tescil edilmek üzere TTSM'ye sunulmuştur.

Anahtar Kelimeler: Otlak ayrığı, bitki boyu, ham protein oranı, verim

\section{Development of Crested Wheatgrass Cultivar for the Middle and Transition Regions of Turkey}

\begin{abstract}
This study was carried out to determine the hay yield and quality of cultivar candidate of crested wheatgrass under Tokat and Sivas ecological conditions during the years of 2013-2015. In the study, one cultivar candidate and two populations of crested wheatgrass were used as plant material. The field trial was designed according to a randomized block design with four replications in the research areas of Central Black Sea Transition Zone Agricultural Research Institute Directorate in Tokat and in Sivas-Sarkisla. Results of the study showed that the materials tested were significantly different in hay yield and quality. The cultivar candidate was the superior in hay yield. From the results of the study, it was concluded that cultivar candidate could be submitted to the TTSM for registration.

Key Words: Crested wheatgrass, plant height, crude protein ratio, hay yield
\end{abstract}

\section{GíRiş̧}

Ülkemizde son yıllarda yem bitkileri tohumculuğunda önemli gelişmeler olmasına rağmen aynı gelişme çok yıllık mera türlerinin tohumculuğunda sağlanamamıştır. Mera tesislerinde kullanılmak üzere ülkemizin farklı ekolojik koşullarına uygun, verimli ve kaliteli ot üreten çeşitlerin geliştirilmesi ve bunların tohumlarının yeterli miktarda üretilmesi gerekir. Çok farklı ekolojik bölgelere sahip olan ülkemiz bir çok yem bitkisi türünün gen merkezi olmasına ve yem bitkisi tohumculuğu için çok uygun ekolojik koşullara sahip olmamıza karşılık ıslah edilmiş çok yıllık yem bitkisi türü, çeşidi çok az sayıdadır. Mera tesislerinde kullanılan tür ve çeşitlerin tohumların genel olarak yurt dışından ithal edilmekte ve milyonlarca dolar döviz ödenmektedir. Yurtdışından ithal edilen mera türlerinin miktarını net olarak belirten bir kayıt olmamasına rağmen ithal edilen yem bitkisi, çim ve çayır otu tohumluk miktarını gösteren veriler elde mevcuttur. 2002 yılında yem bitkisi, çim ve çayır otu ithalatı tohumluk miktarı 2.534 ton iken ithal edilen miktar yıllar içerisinde artmış 2010 yılında 4.627 tona, 2016 yılında ise 11.152 tona ulaşmıştır. Belirtilen bu tohumluk miktarının parasal değeri 2002 yılında 3.473.000, 2010 yılinda 8.670.000 \$, 2016 yılında ise 20.683.000 \$' dir (GTHB, 2017). Ayrica ithal edilen bu tohumların kullanıldıkları alanları ekolojik koşullarına tam olarak adapte olamadıkları için çoğu kez mera tesis çalışmaları başarısız olmuştur.

Kaba yem açığının kapatılmasında meralar önemli bir yere sahiptir. Mera ıslahında kullanılmak üzere çok yıllık buğdaygil ve baklagil yem bitkisi çeşitlerinin ıslah edilmesi ve bunların tohumlarının yeterli miktarda üretilmesi ile bir gen merkezi olan ülke kaynaklarından yerinde kullanım sağlanmış olacak ve ithalat yoluyla ülke dışına gitmekte olan kaynak kaybı önlenecektir.

Otlak ayrığı; kurak koşullarda daha çok otlatılarak yararlanılan, ilkbaharda diğer çoğu türe göre 2-4 hafta erken gelişen, yaz dönemini dormant geçiren, sonbahar yağışları ile tekrar otlatılacak düzeyde gelişme gösteren serin mevsim buğdaygil yem bitkisidir. Otlak ayrığı, birinci yılda gelişimi yavaş, ikinci ve üçüncü yılda kuru ot verimi ve tohum üretimi bakımından iyi gelişen, 40 $\mathrm{cm}$ sıra aralığında en iyi gelişmeyi gösteren, ham 
protein oranının çiçeklenme öncesi \% 22.7 iken başaklanma ve çiçeklenme döneminde sırasıyla \% 13.9, $\% 11.7$ olduğu ve tohum olgunluğunda bu oranın \% 8.5'e kadar düştüğü (Altın ve ark, 2009) bir çok y1llık türdür.Her sınıftan evcil hayvanlar için vejetatif büyüme devresinde çok iyi yem sağlayan, ilkbaharda çiftlik hayvanları tarafindan sevilerek yenilen, sığırlar için iyi bir mera oluşturan (Sedevic and Barker, 1998), ileri olgunluk devresinde hayvanlar tarafindan tercih edilmeyen (Assay, 1993) bir mera bitkisidir.

$\mathrm{Bu}$ araştırma ile orta ve geçit bölgelerine uygun, otlak ayrığı çeşit adayının ot verimi ve kalitesinin belirlenerek tescile sunulması amaçlanmıştır.

\section{MATERYAL ve METOT}

$\mathrm{Bu}$ araștırma, 2013-2015 yılları arasında iki yıl süreyle Orta Karadeniz Geçit Kuşağı Tarımsal Araştırma İstasyonu Müdürlüğü'nün Tokat ve SivasŞarkışla'da bulunan deneme alanlarında yürütülmüştür. Denemelerde Sivas ve Tokat meralarından toplanan otlak ayrığı popülasyonlarından toptan seleksiyon yöntemi ile selekte edilerek geliştirilen 20 klondan oluşan bir adet otlak ayrığı çeşit adayı ile Sivas popülasyonu ve Erzurum islah popülasyonu materyal olarak kullanılmıştır. Gaziosmanpaşa Üniversitesi Ziraat Fakültesi Toprak Analizi Laboratuarında yapılan analiz sonuçlarına göre her iki deneme alanı toprakları; killi tınlı, tuzsuz, hafif alkali, bitkiler tarafindan alınabilir fosfor ve potasyum yönünden zengin, organik madde ve kireç bakımından orta düzeyde bir toprak özelliğine sahiptir (Aydeniz ve Brohi, 1991). Meteoroloji Genel Müdürlüğü verilerine göre, araştırmanın yürütüldüğü yıllar ve uzun yıllar aylık sicaklık ortalaması Tokat lokasyonunda, $12.2, \quad 13.4$ ve $12.5^{\circ} \mathrm{C}, \quad$ Sivas lokasyonunda; $9,0,10.2$ ve $9.3^{\circ} \mathrm{C}$, aylık toplam yağış miktarı Tokat lokasyonunda 267.5, 399.3 ve $443.7 \mathrm{~mm}$, Sivas lokasyonunda 242.3, 312.3 ve $385.5 \mathrm{~mm}$ ve ortalama nispi nem oranı ise Tokat lokasyonunda, \% $66.4, \% 68.6$ ve $\%$ 62.5, Sivas lokasyonunda ise $\% 63.4$,
62.0 ve 62.3 olarak kaydedilmiştir. Buna göre deneme yıllarının uzun yıllardan daha az yağışı geçtiğini söyleyebiliriz.

Çeşit adayı ve popülasyonların her birisi $40 \mathrm{~cm}$ aralıklı $5 \mathrm{~m}$ uzunluğundaki 8 sıradan oluşan parsellere ekilmiştir. Ekimde tohumluk miktarı $1.2 \mathrm{~kg} \mathrm{da}^{-1}$ olarak alınmış ve ekim öncesi parsellere $10 \mathrm{~kg} \mathrm{da}^{-1}$ saf azot, 5 $\mathrm{kg} \mathrm{da} \mathrm{da}^{-1}$ saf fosforlu gübre uygulanmıştır (Anonim, 2001). Denemeler her iki lokasyonda 4 tekrarlamal, tesadüf blokları deneme desenine uygun olarak kurulmuştur. Hasat; başaklanma başlangıcında yapılmıştır. Hasatta her parselde yanlardan birer sıra ve parsel başı ile sonundan 0.5 m'lik kısım kenar tesiri olarak biçilip atıldıktan sonra, geriye kalan $4 \mathrm{~m}$ uzunluğundaki 6 sıra biçilmiştir. 2013 yılı tesis yılı olduğundan dolayı kök gelişimi amacıyla herhangi bir hasat yapılmamıştır. Her iki lokasyonda her yıl ikişer biçim yapılmıştır. Her parselden alınan 500 gr ot örneği $70{ }^{\circ} \mathrm{C}$ 'ye ayarlanmıș firında 24 saat kurutulduktan sonra tartılmıştır. Bu örnekler kalite analizleri için $1 \mathrm{~mm}$ 'lik elekten geçecek şekilde ögütüldükten sonra, Kjeldahl cihazıyla örneklerin azot içeriği saptanmış, saptanan azot değerleri 6.25 katsayısı ile çarpılarak ham protein oranı değerleri hesaplanmıștır.

Her parselde; bitki boyu, yaş ot verimi, kuru ot verimi ve ham protein oran1, Anonim (1995), Anonim (2001) ve Şehirali (2002) tarafindan açıklanan yöntemlere göre saptanmıştır. Araştırmadan elde edilen verilerin değerlendirilmesinde, MSTAT-C istatistik paket programı kullanılarak tesadüf blokları deneme desenine uygun olarak varyans analizi uygulanmıştır. Varyans analizi sonuçlarına göre istatistiksel olarak önemli çıkan faktör ortalamaları LSD testi ile karşılaştırılmıştır (Düzgüneş ve ark. 1987).

\section{BULGULAR ve TARTIŞMA}

Bitki Boyu): Araştırmada incelenen çeşit adayı ve popülasyonların bitki boyu ortalamaları Çizelge 1'de verilmiştir.

Çizelge 1. Araştırmada incelenen otlak ayrığı materyalinde bitki boyu ortalamaları $(\mathrm{cm})$

\begin{tabular}{|l|c|c|c|}
\hline \multirow{2}{*}{ Çeşit adayı ve popülasyonlar } & \multicolumn{3}{|c|}{ Ana Sap Uzunluğu (cm) } \\
\cline { 2 - 4 } & \multicolumn{3}{|c|}{ Tokat Lokasyonu } \\
\cline { 2 - 4 } & $\mathbf{2 0 1 4}$ & $\mathbf{2 0 1 5}$ & Ortalama \\
\hline Sivas popülasyon & $71.9 \mathrm{c}^{*}$ & $44.5 \mathrm{~b}$ & $58.2 \mathrm{~b}$ \\
\hline Çeşit adayı & $80.6 \mathrm{a}$ & $53.3 \mathrm{a}$ & $67.0 \mathrm{a}$ \\
\hline Erzurum 1slah popülasyon & $76.0 \mathrm{~b}$ & $42.2 \mathrm{~b}$ & 61.4 \\
\hline Ortalama & $76.1 \mathrm{~A}^{* *}$ & $46.7 \mathrm{~B}$ & $61.8 \mathrm{c}$ \\
\hline \multicolumn{3}{|c|}{ Sivas Lokasyonu } \\
\hline Sivas popülasyon & $60.0 \mathrm{c}^{*}$ & $61.6 \mathrm{c}$ & $84.5 \mathrm{a}$ \\
\hline Çeşit adayı & $80.1 \mathrm{a}$ & $89.0 \mathrm{a}$ & $72.4 \mathrm{~b}$ \\
\hline Erzurum 1slah popülasyon & $73.4 \mathrm{~b}$ & $74.4 \mathrm{~b}$ & 73.1 \\
\hline Ortalama & $71.2 \mathrm{~B} * *$ & $75.0 \mathrm{~A}$ & \\
\hline
\end{tabular}

*Aynı sütun içerisinde benzer harf ile gösterilen ortalamalar, LSD testine göre, $\mathrm{P} \leq 0,05$ hata sınırları içerisinde birbirlerinden farksızdır. **Aynı satır içerisinde benzer harf ile gösterilen ortalamalar, $\mathrm{P} \leq 0,01$ hata sınırları içerisinde birbirlerinden farksızdır.

Çizelge 1'de görüldüğü üzere her iki lokasyonda çeşit adayı ve populasyonlar ile yıllar bitki boyunda istatistiki olarak önemli farklar yaratmıştır. Her iki lokasyonda en yüksek bitki boyu çeşit adayında belirlenmiştir. Tokat lokasyonunda ortalama bitki boyu $61.4 \mathrm{~cm}$ iken Sivas lokasyonunda $73.1 \mathrm{~cm}$ olarak 
gerçekleşmiştir. Otlak ayrığında bitki boyunu Açıkgöz (1982) 84.3-105.5 cm, Serin (1989) 87.0 cm, Karakurt ve Ekiz (2000) $66.8 \mathrm{~cm}$ olarak bildirmişlerdir. Araştırma ile elde edilen bitki boyu, Açıkgöz (1982) ve Serin (1989)'den daha düşük Karakurt ve Ekiz (2000)'den daha yüksektir. Bunun ekoloji, çeşit ve bakım farklılıklarından kaynaklandığını söyleyebiliriz.

\section{Yas Ot Verimi:}

Araştırmada incelenen otlak ayrığı materyalinde yaş ot verimleri ortalama değerleri Çizelge 2'de verilmiştir.

Çizelge 2. Araştırmada incelenen otlak ayrığı materyalinde yaș ot verimi ortalamaları $\left(\mathrm{kg} \mathrm{da}^{-1}\right)$

\begin{tabular}{|l|c|c|c|}
\hline \multirow{2}{*}{ Çeşit adayı ve populasyonlar } & \multicolumn{3}{|c|}{ Tokat Lokasyonu } \\
\cline { 2 - 4 } & $\mathbf{2 0 1 4}$ & $\mathbf{2 0 1 5}$ & Ortalama \\
\hline Sivas populasyon & $1689.9 \mathrm{~b}$ & $953.4 \mathrm{~b}$ & $1321.7 \mathrm{~b}$ \\
\hline Çeşit adayı & $1793.6 \mathrm{a}$ & $1017.5 \mathrm{a}$ & $1405.6 \mathrm{a}$ \\
\hline Erzurum sslah populasyon & $1721.5 \mathrm{ab}$ & $969.4 \mathrm{~b}$ & $1345.5 \mathrm{~b}$ \\
\hline Ortalama & $1735.0 \mathrm{~A}^{* *}$ & 980.1 & 1357.6 \\
\hline \multicolumn{3}{|c|}{ Sivas Lokasyonu } \\
\hline Sivas populasyon & $1380.5 \mathrm{~b}^{*}$ & $1341.8 \mathrm{~b}$ & $1361.2 \mathrm{~b}$ \\
\hline Çeşit adayı & $1533.3 \mathrm{a}$ & $1657.4 \mathrm{a}$ & $1595.4 \mathrm{a}$ \\
\hline Erzurum 1slah populasyon & $1494.0 \mathrm{ab}$ & $1544.4 \mathrm{a}$ & $1519.2 \mathrm{a}$ \\
\hline Ortalama & $1469.3 \mathrm{~B} * *$ & $1514.5 \mathrm{~A}$ & 1491.9 \\
\hline
\end{tabular}

${ }^{*}$ Aynı sütun içerisinde benzer harf ile gösterilen ortalamalar, LSD testine göre, $\mathrm{P} \leq 0,05$ hata sınırları içerisinde birbirlerinden farksızdır. **Aynı satır içerisinde benzer harf ile gösterilen ortalamalar $\mathrm{P} \leq 0,01$ hata sınırları içerisinde birbirlerinden farksızdır.

Çizelge 2'de görüldüğü üzere her iki lokasyonda çeşit adayı ve poulasyonlar ile yıllar, yaş ot verimlerinde istatistiki olarak önemli farklar yaratmıştır. Her iki lokasyonda en yüksek yaş ot verimi çeşit adayında saptanmıştır. Tokat lokasyonunda ortalama yaş ot verimi $1357.6 \mathrm{~kg} \mathrm{da}^{-1}$ iken Sivas lokasyonunda $1491.9 \mathrm{~kg} \mathrm{da}^{-1}$ olarak gerçekleşmiştir. Karakurt ve Ekiz (2000) Ankara koşullarında yapmış olduğu bir araştırmada otlak ayrığında yaş ot verimini $1476.8 \mathrm{~kg}$ $\mathrm{da}^{-1}$ olarak bildirmişlerdir. Yeşil ot verimindeki farklılı̆ıın ekoloji, bakım ve çeşit farklılıklarından kaynaklanmış olabileceğini söyleyebiliriz.

\section{Kuru Ot Verimi:}

Araştırmada incelenen otlat ayrı̆̆ı materyalinde kuru ot verimleri ortalama değerleri Çizelge 3 'de verilmiştir.

Çizelge 3.Araştırmada incelenen otlak ayrığı materyalinde kuru ot verimi ortalamaları $\left(\mathrm{kg} \mathrm{da}^{-1}\right)$

\begin{tabular}{|l|c|c|c|}
\hline \multirow{2}{*}{ Çeşit adayı ve popülasyonlar } & \multicolumn{3}{|c|}{ Tokat Lokasyonu } \\
\cline { 2 - 4 } & $\mathbf{2 0 1 4}$ & $\mathbf{2 0 1 5}$ & Ortalama \\
\hline Sivas popülasyon & $734.3 \mathrm{~b}^{*}$ & $394.4 \mathrm{a}$ & $564.4 \mathrm{ab}$ \\
\hline Çeşit adayı & $764.0 \mathrm{a}$ & $377.1 \mathrm{~b}$ & $570.6 \mathrm{a}$ \\
\hline Erzurum sslah popülasyon & $716.6 \mathrm{c}$ & $392.0 \mathrm{a}$ & $554.3 \mathrm{~b}$ \\
\hline Ortalama & $738.3 \mathrm{~A}^{* *}$ & $387.7 \mathrm{~B}$ & 563.0 \\
\hline \multicolumn{3}{|c|}{ Sivas Lokasyonu } \\
\hline Sivas popülasyon & $599.9 \mathrm{~b}$ & $567.0 \mathrm{~b}$ & $583.5 \mathrm{~b}$ \\
\hline Çeşit adayı & $652.8 \mathrm{a}$ & $709.0 \mathrm{a}$ & $680.9 \mathrm{a}$ \\
\hline Erzurum 1slah popülasyon & $621.6 \mathrm{ab}$ & $709.9 \mathrm{a}$ & $665.8 \mathrm{a}$ \\
\hline Ortalama & $624.8 \mathrm{~B} * *$ & $662.0 \mathrm{~A}$ & 643.4 \\
\hline
\end{tabular}

*Ayn1 sütun içerisinde benzer harf ile gösterilen ortalamalar, LSD testine göre, $\mathrm{P} \leq 0,05$ hata sınırları içerisinde birbirlerinden farksızdır. **Aynı satır içerisinde benzer harf ile gösterilen ortalamalar $\mathrm{P} \leq 0,01$ hata sınırları içerisinde birbirlerinden farksızdır.

Çizelge 3'de görüldüğü üzere her iki lokasyonda çeșit aday ve populasyonlar ile y1llar, kuru ot verimlerinde istatistiki olarak önemli farklar yaratmıştır. Her iki lokasyonda en yüksek kuru ot verimi çeşit adayında saptanmıştır. Tokat lokasyonunda ortalama kuru ot verimi $563.0 \mathrm{~kg} \mathrm{da}^{-1}$ iken Sivas lokasyonunda $643.4 \mathrm{~kg} \mathrm{da}^{-1}$ olarak gerçekleşmiştir. Otlak ayrığında kuru ot verimini Altın (1982) 305.4-676.8 kg da-1 Holt ve Zentner (1985), 190.0-433.0 kg da ${ }^{-1}$, Serin (1989), 240.6-511.5 kg da ${ }^{-1}$, Karakurt ve Ekiz (2000), $607.9 \mathrm{~kg}$ $\mathrm{da}^{-1}$ olarak bildirmişlerdir. Her iki lokasyondan elde edilen kuru ot verimi değerleri Altın (1982), Karakurt ve Ekiz (2000) ile uyumlu iken Holt ve Zentner (1985), Serin (1989) ile uyumlu olmadığı görülmüştür. Bunun nedeninin ekoloji, çeşit ve bakım farklılığından kaynaklanmış olabileceğini söyleyebiliriz.

\section{Ham Protein Orant:}

Araştırmada incelenen otlak ayrı $\breve{g} 1$ materyalinde ham protein oranı ortalama değerleri Çizelge 4'de verilmiştir. Çizelge 4'de görüldüğü üzere Tokat lokasyonunda 2014 yılı ve iki yıllık ortalamalarda çeşit adayı ve popülasyonlar, ham protein oranlarında istatistiki olarak önemli farklar yaratmıştır. 
Çizelge 4. Araştırmada incelenen otlak ayrığı materyalinde ham protein oranı ortalama değerleri (\%)

\begin{tabular}{|l|c|c|c|}
\hline \multirow{2}{*}{ Çeşit adayı ve popülasyonlar } & \multicolumn{3}{|c|}{ Tokat Lokasyonu } \\
\cline { 2 - 4 } & $\mathbf{2 0 1 4}$ & $\mathbf{2 0 1 5}$ & Ortalama \\
\hline Sivas popülasyon & $13.3 \mathrm{a}^{*}$ & 13.2 & $13.3 \mathrm{a}$ \\
\hline Çeşit adayı & $13.2 \mathrm{a}$ & 13.1 & $13.2 \mathrm{a}$ \\
\hline Erzurum 1slah popülasyon & $11.9 \mathrm{~b}$ & 12.6 & $12.3 \mathrm{~b}$ \\
\hline Ortalama & 12.8 & 13.0 & 11.5 \\
\hline \multicolumn{3}{|c|}{ Sivas Lokasyonu } \\
\hline Sivas popülasyon & 10.7 & 12.2 & 11.0 \\
\hline Çeşit adayı & 10.9 & 11.1 & 12.0 \\
\hline Erzurum 1slah popülasyon & 12.3 & 11.6 & 11.5 \\
\hline Ortalama & 11.3 & 11.6 & \\
\hline
\end{tabular}

*Aynı sütun içerisinde benzer harf ile gösterilen ortalamalar, LSD testine göre, $\mathrm{P} \leq 0,05$ hata sınırları içerisinde birbirlerinden farksızdır.

İki yıllık ortalamada en düşük ham protein oranı (\%12.3) Erzurum 1slah popülasyonunda saptanmıştır. Sivas lokasyonunda ise çeşit adayı ve populasyonlar istatistiki olarak önemli farklılık göstermemiş iki yıllık ham protein oranı ortalaması $\% \quad 11.5$ olarak gerçekleşmiştir. Otlak ayrığında ham protein oranını Açıkgöz (1982) \% 10.0-19.6, Serin (1989) \% 10.0-13.1, Karakurt ve Ekiz (2000) \% 12.3 olarak bildirmişlerdir.
Araştırmadan elde edilen ham protein oranlarının yukarıda belirtilen bulgular ile uyumlu olduğunu söyleyebiliriz.

\section{Ham Protein Verimi:}

Araştırmada incelenen çeşit adayı ve popülasyonların ham protein verimleri ortalama değerleri Çizelge 5'de verilmiştir.

Çizelge 5. Araştırmada incelenen otlak ayrı̆̆ı materyalinde ham protein verimi ortalama değerleri $\left(\mathrm{kg} \mathrm{da}^{-1}\right)$

\begin{tabular}{|l|c|c|c|}
\hline \multirow{2}{*}{ Çeşit adayı ve popülasyonlar } & \multicolumn{3}{|c|}{ Tokat Lokasyonu } \\
\cline { 2 - 4 } & $\mathbf{2 0 1 4}$ & $\mathbf{2 0 1 5}$ & Ortalama \\
\hline Sivas popülasyon & $97.7 \mathrm{ab}$ & $52.1 \mathrm{a}$ & $75.1 \mathrm{a}$ \\
\hline Çeşit adayı & $100.8 \mathrm{a}$ & $49.4 \mathrm{~b}$ & $75.3 \mathrm{a}$ \\
\hline Erzurum 1slah popülasyon & $85.3 \mathrm{~b}$ & $49.4 \mathrm{~b}$ & $68.2 \mathrm{~b}$ \\
\hline Ortalama & $94.5 \mathrm{~A}^{* *}$ & $50.4 \mathrm{~B}$ & 72.6 \\
\hline \multicolumn{3}{|c|}{ Sivas Lokasyonu } \\
\hline Sivas popülasyon & $64.2 \mathrm{c}^{*}$ & $69.2 \mathrm{c}$ & $67.1 \mathrm{c}$ \\
\hline Çeşit adayı & $71.2 \mathrm{~b}$ & $78.7 \mathrm{~b}$ & $74.9 \mathrm{~b}$ \\
\hline Erzurum 1slah popülasyon & $76.5 \mathrm{a}$ & $82.3 \mathrm{a}$ & $79.9 \mathrm{a}$ \\
\hline Ortalama & $70.6 \mathrm{~B} * *$ & $77.0 \mathrm{~A}$ & 74.0 \\
\hline
\end{tabular}

*Aynı sütun içerisinde benzer harf ile gösterilen ortalamalar, LSD testine göre, $\mathrm{P} \leq 0,05$ hata sınırları içerisinde birbirlerinden farksızdır. **Aynı satır içerisinde benzer harf ile gösterilen ortalamalar, $\mathrm{P} \leq 0,01$ hata sınırları içerisinde birbirlerinden farksızdır.

Çizelge 5'de görüldüğü üzere her iki lokasyonda çeşit adayı ve populasyonlar ile yıllar, ham protein verimlerinde istatistiki olarak önemli farklar yaratmıştır. En yüksek ham protein verimi, Tokat lokasyonunda çeşit adayında Sivas lokasyonunda ise Erzurum 1slah popülasyonunda saptanmıştır. Ham protein verimi Tokat lokasyonunda ortalama $72.6 \mathrm{~kg} \mathrm{da}^{-1}$ iken Sivas lokasyonunda ise $74.0 \mathrm{~kg} \mathrm{da}^{-1}$ olarak gerçekleşmiştir. Ham protein verimi ham protein oranları ile kuru ot verimlerinden elde edilen bir değer olduğundan dolayı genel olarak kuru ot verimi ve ham protein oranı yüksek olan genotiplerin de ham protein verimi yüksek bulunmuştur. Ham protein verimini Altın (1982) 40.4103.2, Serin (1989) 24.0-67.6 kg da ${ }^{-1}$, Karakurt ve Ekiz (2000) 61.5-105.0 $\mathrm{kg} \mathrm{da}$ olarak bildirmişlerdir. Araştırmadan elde edilen ham protein verimlerinin Altın (1982), Karakurt ve Ekiz (2000) ile uyumlu olduğunu Serin (1989)'den yüksek olduğunu, bunun nedeninin ise farklı ekoloji, bakım ve çeşitten kaynaklanmış olabileceğini söyleyebiliriz.

\section{SONUÇ}

Araştırma sonuçlarına göre; en yüksek bitki boyu, yaş ot verimi, kuru ot verimi çeşit adayında belirlenmiştir. Çeşit adayının tescile sunulmasına karar verilmiştir.

\section{TEŞEKKÜR}

$\mathrm{Bu}$ bildiri $113 \mathrm{O} 012$ nolu TÜBİTAK projesinden elde edilen verilerden hazırlanmıștır. Desteklerinden dolayı TÜBİTAK’a teşekkür ederiz.

\section{KAYNAKLAR}

Açıkgöz E 1982. Adi otlak ayrığı (Agropyron cristatım (L) Gaertn.)"nda bazı morfolojik ve tarımsal özellikler ile çiçek biyolojisi üzerinde araştırmalar. Ankara Univ. Zir. Fak. Yayınları: 802. Bilimsel 
Araştırma ve İncelemeler: 475, Ankara.

Altın M 1982. Erzurum şartlarında bazı yem bitkileri ile bunların karışımlarının değişik azot dozlarmdaki kuru ot ve ham protein verimleri ile karışımların botanik kompozisyonu. TÜBİTAK VII. Bilim Kongresi 552/TOAG 115. s: 327-362.

Altın M, Tekeli A.S. ve Nizam İ 2009. Ayriklar, Buğdaygil ve Diğer Familyalardan Yem Bitkileri, (Avcıoğlu R. Hatipoğlu R. Karadağ Y. Edit.) Cilt III. TÜGEM, Emre Basımevi, İzmir, s: 573-589

Anonim 1995. The Determination Of Nitrogen According To Kjeldahl Using Block Digestion And Steam Distilation. Tecator Application Note An 300, Tecator Ab Sweden, P: 1-11

Anonim 2001. Tarımsal Değerleri Ölçme Denemeleri Teknik Talimatı. Buğdaygil Yem Bitkileri Tarımsal Değerler Ölçme Denemeleri. Tc. Tar. Ve Köy. Bak. Kor. Ve Kont. Gen. Müd. Toh. Tes. Ve Sertifikasyon Mer. Müd.

Assay KH 1993. Plant Exploration for New Forage Grasses. P: 147-154. In: J.Janic and J.E.Simon (eds.), New Crops. Wiley, Newyork.

Aydeniz A, Brohi AR, 1991. Gübreler ve Gübreleme. C.Ü. Tokat Ziraat Fakültesi Yayınları, Yayın No. 10, Ders Kitabı 3, Tokat.
Düzgüneş O, Kesici T, Kavuncu O, Gürbüz F 1987. Araştırma Ve Deneme Metodları, Ankara Üniv. Zir. Fak. Yayınları, No: 295, Ankara.

GHTB, 2017. www.tarim.gov.tr 27.11.2017

Holt NW ve Zentner RP 1985. Effects of applying inorganic fertilizer and farmyard manure on forage production and economic retums in east-central Saskatchewan. Can. J. Plant Sc1. 65 (3): 597-607.

Karakurt E ve Ekiz H 2000. Bazı Buğdaygil Yem Bitkilerinde Azotlu Gübre Dozlarının Önemli Tarımsal Karakterler Üzerine Etkileri, Tarla Bitkileri Merkez Araştırma Enstitüsü Dergisi (9). 1-11, Ankara

Sedevic KK, ve Barker WT 1998. Selected North Dakota and Minnesota Range Plants. Eb-69. North Dakota State University Agriculture and University. http://www.ag.ndsu.edu/pubs/ansci/range/eb696.htm

Serin Y 1989. Sonbahar Ve İlkbaharda Uygulanan Azotlu Gübrelerin Otlak Ayrığı (Agropyron cristatum)'nın Tohum Verimi Ve Verim Unsurlarına Etkileri, Atatürk Üniversitesi Ziraat Fakültesi Dergisi, 20 (2)

Şehirali S 2002. Tohumluk Ve Teknolojisi. Trakya Üniv. Tekirdağ Zir. Fak. Tarla Bit. Böl. Yenilenmiş 3. Bask1, İstanbul, $464 \mathrm{~S}$. 